УДК 343.98

DOI https:/ / doi.org/10.32837 / yuv.v0i4.1976

В. Арешонков,

кандидат юридичних наук, старший науковий співробітник, провідний науковий співробітник наукової лабораторії з проблем протидії злочинності Навчально-наукового інституту № 1

Національної академії внутрішніх справ

\title{
ТЕХНІКО-КРИМІНАЛІСТИЧНІ ДОСЛІДЖЕННЯ ЯК БАЗОВА КАТЕГОРІЯ КРИМІНАЛІСТИЧНОЇ ТЕХНІКИ: ПОНЯТТЯ ТА ОЗНАКИ
}

Розділ криміналістики, який сьогодні має назву «Криміналістична техніка», почав формуватися одним із перших ще наприкінці XIX - на початку XX століть і з того часу продовжує активно розвиватись і доповнюватись.

У межах вказаного розділу в підручниках 3 криміналістики та монографіях на дану тематику такими авторами, як Т.В. Авер'янова, Р.С. Бєлкін, A.I. Вінберг, В.Г. Гончаренко, O.M. Зінін, А.В. Іщенко, Н.I. Кліменко, В.О. Коновалова, І.В. Пиріг, M.В. Салтевський, М.Я. Сегай, В.Ю. Шепітько, М.Г. Щербаковський та іншими, досить детально, 3 наведенням понять, розкриттям змісту та класифікаціями, розглядаються такі базові для даного розділу поняття, як «техніко-криміналістичні засоби» [1, с. 53], «техніко-криміналістичні прийоми» [2, с. 151], «техніко-криміналістичні методи» [3, с. 52], «техніко-криміналістичне забезпечення» [4, с. 26], проте така основоположна категорія, як «техніко-криміналістичні дослідження», чітко не визначена.

Разом із тим, як слушно зауважують М.В. Салтевський та деякі інші криміналісти, саме дослідження речових доказів із застосуванням технічних засобів було початком зародження такого розділу криміналістики, як «Криміналістична техніка» [5, с. 93-94].
Метою даної статті $€$ визначення ознак техніко-криміналістичних досліджень та на основі цього формулювання поняття даної категорії, яка $є$ базовою для такого розділу криміналістики, як криміналістична техніка.

Щодо власне словосполучення «техніко-криміналістичні дослідження», то в більшості випадків у літературі 3 криміналістики воно вживається відносно досліджень документів і ним позначається галузь криміналістичної техніки з однойменною назвою, предметом якої $€$ вивчення способів виготовлення і підроблення письмових документів [6, с. 352].

Додавання в цьому випадку слова «техніко-» або ж «технічне дослідження», яким позначається відношення до техніки або те, що вивчатись буде технічна сторона чогось, на нашу думку, є уточнюючим, оскільки так само може застосовуватись і з іншими видами досліджень (наприклад, криміналістичним дослідженням зброї, яка є власне технічним засобом, вивчатись може іiі технічний стан та при цьому застосовуватися різні технічні засоби).

Термін «техніко-криміналістичні дослідження» без віднесення його до дослідження документів майже не вживається в науковій літературі. Виключення становлять підручник «Криміналістика» авторів Л.Я. Драпкіна та В.М. Карагодіна. У параграфі, присвяченому поняттю і структурі 
криміналістичної техніки, вони зазначають, що «при проведении исследований в области криминалистической техники не могут не учитываться развитие научно-технического прогресса. В тоже время результаты технико-криминалистических исследований используются при проведении изысканий в отдельных отраслях науки и техники» $[7$, с. 80-81]. Проте, далі пояснюючи зазначене ними твердження, наводиться приклад, коли під час проведення техніко-криміналістичних досліджень у випадку виготовлення підроблених документів ураховуються принципи діï засобів комп'ютерної техніки, а виявлені недоліки захисту документів узагальнюються і враховуються іiі виробниками.

Оскільки автори зазначеного підручнику не наводять визначення поняття «техніко-криміналістичні дослідження» та не розкривають його значення, то, по-перше, не зрозуміло, чи не ототожнюють вони, виходячи з наведеного прикладу, "техніко-криміналістичні дослідження» 3 «техніко-криміналістичними дослідженнями документів»; по-друге, навіть розділяючи ці поняття, не зрозуміло, про яку категорію досліджень тут ідеться про наукові чи практичні дослідження. Разом із тим ми вважаємо, що це не тотожні між собою поняття, до того ж дослідження за своїм характером або ж сферою проведення можуть поділятись як на теоретичні (наукові), так і прикладні (практичні).

Іншим джерелом, де згадується досліджуване нами поняття, є стаття Я. Лазора, Б. Русина, В. Цибочкина, присвячена апаратно-програмному підходу до техніко-криміналістичних досліджень об'єктів для розкриття злочинів. У ній використовується термін «техніко-криміналістичні дослідження речових носіїв доказів», проте жодним чином не розкривається його визначення та ознаки. Більше того, зі статті не зрозумілим є співвідношення між собою техніко-криміна- лістичних досліджень та криміналістичних експертиз, оскільки в одному випадку авторами зазначається, що експертні дослідження, до яких фактично відносяться і криміналістичні експертизи, - це етап техніко-криміналістичного дослідження, водночас в іншому - техніко-криміналістичні дослідження вживаються на одному рівні із судовими експертизами, тобто виходить, що це різні дослідження [8, с. 209-210].

Згідно 3 лексичним значенням словосполучення «техніко-криміналістичне» відносно власне дослідження означає: по-перше, що воно відноситься до криміналістики; по-друге, що таке дослідження пов'язане з технікою як сукупністю засобів і знарядь праці в певній галузі [9, с. 465, 1244]. Проте, на нашу думку, в межах самої криміналістики як науки дане словосполучення може мати й інше лексичне значення, а саме означати, що дослідження відносяться або ж пов'язані 3 таким розділом криміналістики, як криміналістична техніка. Відповідно, дослідження, які передбачені розділом криміналістики - криміналістичною технікою, та про які, власне, зазначається у визначеннях даного поняття, будуть називатись техніко-криміналістичними.

Оскільки визначення поняття - це логічна операція, за допомогою якої розкривається його зміст, відповідно, потрібно розкрити істотні характеристики поняття, що нами визначається, а саме «техніко-криміналістичні дослідження», виділити його загальні та специфічні (окремі) ознаки.

Відносно особливостей (ознак) техніко-криміналістичних досліджень, на нашу думку, необхідно виділити декілька критеріїв їх поділу на групи:

1. 3a належністю: притаманні як техніко-криміналістичним, так й іншим криміналістичним дослідженням (загальні); притаманні виключно техніко-криміналістичним дослідженням у цілому (окремі для всіх технікокриміналістичних досліджень, для 
конкретного різновиду досліджень є загальними); притаманні окремим різновидам техніко-криміналістичних досліджень (окремі);

2. За обов'язковістю: обов'язкові та факультативні (варіативні).

Згідно $з$ академічним тлумачним словником української мови термін «досліджувати» означає ретельно обстежувати кого-, що-небудь, уважно знайомитися 3 чим-небудь для встановлення чогось [10, с. 550].

У криміналістиці існують досить різні визначення даного поняття. Наприклад, щодо доказів, то в підручнику «Криминалистическая экспертиза» за редакцією Р.С. Бєлкіна під дослідженнями розуміється пізнання особою, яка здійснює дізнання, слідчим, суддями змісту доказів, перевірку достовірності існування тих фактичних даних, які становлять зміст доказу, з'ясування відношення даного доказу до всіх інших доказів у справі [11, с. 6].

У наукових джерелах існують навіть дещо алогічні інтерпретації даного терміна, наприклад, що «дослідження - це сукупність операції, яка складається 3 операції 3 визначення предмета дослідження хоча б в одному об'єкті дослідження у відповідності 3 поставленим питанням» [12, с. 62].

Проте загальним $€$ те, що, по-перше, дослідження - це пізнання або процес отримання чогось нового, які здійснюються шляхом вивчення певного об'єкта або їх сукупності. Тобто незалежно від того, хто здійснює дослідження - слідчий, детектив, спеціаліст чи експерт, незалежно від різновиду такого дослідження чи безпосереднього об'єкту сутність дослідження буде полягати в пізнанні (вивченні) об'єкту шляхом, наприклад, спостереження, вимірювання, порівняння, моделювання тощо. По-друге, метою такого пізнання $€$ отримання нових знань, невідомої інформаціі. У розслідуванні злочинів інформації, наприклад, про особу зло- чинця, засоби чи знаряддя злочину тощо, або ж ї̈ джерел - різноманітних слідів злочину це $є$ проміжним результатом в отриманні необхідної розшукової або доказової інформації.

Потрібно зауважити, що потреба в пізнанні (вивченні) певного об'єкту та отриманні необхідної інформації виникає не тільки під час здійснення кримінального судочинства. Досить часто окремі різновиди техніко-криміналістичних досліджень проводяться в ході здійснення цивільного, господарського та адміністративного судочинства.

Таким чином, якщо розглядати техніко-криміналістичні дослідження як практичну діяльність із вивчення матеріальних слідів, то необхідно зазначити, що натепер сфера проведення таких досліджень не обмежується тільки кримінальним процесом та, відповідно, вивченням виключно слідів кримінального правопорушення. Якщо говорити про вивчення матеріальних відображень саме кримінального проступку чи злочину, то така діяльність притаманна не техніко-криміналістичним дослідженням взагалі, а техніко-криміналістичним дослідженням у розслідуванні кримінальних правопорушень.

Продовжуючи розгляд ознак техніко-криміналістичних досліджень, необхідно зауважити, що одним з елементів, необхідних для пізнання об'єкта дослідження, є наявність в особи, яка здійснює його вивчення, відповідних знань. Межі таких знань досить широкі, починаючи від властивостей певних об'єктів, їх різновидів та особливостей слідоутворення на різних поверхнях за різних умов, і закінчуючи практичними прийомами проведення досліджень та формулювання конкретних висновків. Такі знання у кримінальному процесі прийнято називати спеціальними.

$\mathrm{y}$ наукових джерелах із криміналістики та кримінального процесу під час розкриття поняття та сутності спеціальних знань слушно наголошується на тому, що такі знання: отри-

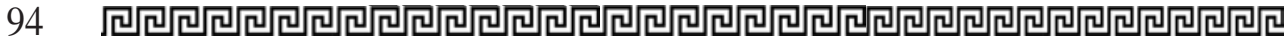


муються в ході спеціальної підготовки та послідуючої практичної діяльності; вони $€$ апробованими, науковими i, відповідно, зафіксованими в науковій літературі, методичних рекомендаціях, настановах, інструкціях тощо $[13$, с. 15]. Окрім цього, в зазначених джерелах до спеціальних знань у тій чи іншій мірі віднесено вміння та навички застосування таких знань на практиці. Проте ми не поділяємо думку щодо включення вмінь та навичок до спеціальних знань. I хоча ці категорії досить тісно пов'язані, вони мають відмінності й повинні розмежовуватись між собою.

Оскільки вміння та навички - це категорії, які безпосередньо пов'язані з діяльністю в певній сфері, а техніко-криміналістичні дослідження в розслідуванні кримінальних правопорушень - це саме діяльність із вивчення певних об'єктів, то для іï успішної реалізації разом зі спеціальними знаннями потрібно також окремо зазначати такі обов'язкові для згаданих досліджень категорії, як «вміння» i «навички». Наприклад, обізнаній особі недостатньо тільки знати типи папілярних візерунків, їхні загальні й окремі ознаки, а також методику проведення ідентифікації людини за слідами пальців рук, потрібно також мати відповідні навички і вміння виявляти такі сліди та проводити дактилоскопічні дослідження.

Досить широке поняття спеціальних знань наводять В.Г. Гончаренко, В.В. Курдюков та К.В. Легких, щоправда, воно також не позбавлене зазначеного вище недоліку. Вони наголошують, що спеціальними знаннями в кримінальному судочинстві $€$ знання і навички, одержані в результаті фахової освіти та/або практичної діяльності в будь-якій галузі науки, техніки, мистецтва або ремесла, які використовуються визначеними законом учасниками процесу в межах наданих кожному з них повноважень для вирішення за певною процедурою процесуальних завдань [14, с. 24].
Згідно з даним визначенням у кримінальному судочинстві можуть використовуватись досить різноманітні спеціальні знання, які можуть не мати жодного відношення до проведення техніко-криміналістичних досліджень як таких, наприклад, залучення до проведення процесуальної дії перекладача як фахівця, який володіє певною мовою, педагога або психолога як спеціалістів у роботі з неповнолітніми тощо.

Відносно власне техніко-криміналістичних досліджень, як щодо їх генезису, так і безпосереднього проведення, справедливо було б говорити не тільки виключно про знання такого розділу криміналістики, як криміналістична техніка. Причин цьому декілька: по-перше, межі таких знань різні автори визначають досить по-різному; по-друге, починаючи з появи перших різновидів технікокриміналістичних досліджень, їм притаманна тісна інтеграція різних наук, наприклад, криміналістики й хімії, фізики, медицини тощо.

Таким чином, використання спеціальних криміналістичних знань для проведення техніко-криміналістичних досліджень $€$ однією 3 характерних ознак таких досліджень.

Разом із тим потрібно зауважити, що для проведення конкретного техніко-криміналістичного дослідження недостатньо просто наявності спеціальних криміналістичних знань (наприклад, рекомендацій щодо пошуку мікрослідів, слідів пальців рук, слідів вибуху тощо та послідуючої лабораторної роботи 3 ними), потрібна людина - відповідний фахівець, який володіє цими знаннями в необхідному об'ємі та може провести таке дослідження.

Кримінальний процесуальний кодекс України володіння спеціальними знаннями прямо передбачає у двох суб'єктів - спеціаліста (ст. 71) та експерта (ст. 69). I хоча суб'єктами-носіями спеціальних знань $€$ й інші особи, наприклад, перекладачі, пси- 
хологи, педагоги, однак спеціальними криміналістичними знаннями вони не володіють взагалі, відповідно й суб'єктами техніко-криміналістичних досліджень вони не можуть бути. Водночас і не всі спеціалісти та експерти є суб'єктами техніко-криміналістичних досліджень. Такими суб'єктами є тільки та частина, яка, як уже зазначалось, володіє саме спеціальними криміналістичними знаннями.

Окрім спеціаліста та експерта, як слушно зауважує О.В. Фролов, суб'єктом застосування спеціальних знань у кримінальному провадженні в окремих випадках може бути безпосередньо особа, що проводить розслідування [15, с. 80-82]. На нашу думку, це твердження стосується в тому числі й застосування такими особами спеціальних криміналістичних знань і проведення ними окремих різновидів техніко-криміналістичних досліджень. Наприклад, слідчий чи детектив для пошуку та огляду об'єктів може не залучати спеціаліста-криміналіста, а здійснити це самостійно, якщо в нього вистачає на це необхідних знань, умінь та навичок.

Потрібно також зауважити, що суб'єкти техніко-криміналістичних досліджень повинні бути правомочні на проведення того чи іншого різновиду дослідження. Одним з елементів такої правомочності, як зазначалось вище, є володіння спеціальними криміналістичними знаннями, проте це не всі умови.

Відносно спеціаліста, то для появи в нього повноважень, передбачених КПК України, особа, яка проводить слідчу (розшукову) дію, повинна відповідним чином залучити спеціаліста, відобразивши про таке залучення в протоколі проведення слідчої діï. Тобто на відміну від спеціаліста, для залучення особи як експерта недостатнім $є$ тільки факт володіння нею спеціальними знаннями. Згідно з ч. 2 та ч. 3 ст. 10 Закону України «Про судову експертизу» такі особи повинні мати вищу освіту, освіт- ньо-кваліфікаційний рівень не нижче спеціаліста, пройти відповідну підготовку, отримати кваліфікацію судового експерта 3 певної спеціальності та бути внесеними в Державний Реєстр атестованих судових експертів. За існування цих умов, за наявності постанови про призначення експертизи або відповідної заяви сторони захисту визначений експерт стає правомочним на проведення криміналістичної експертизи або дослідження (у даному випадку це та ж експертиза, проте назва залежить від суб'єкта ї призначення (замовлення)).

Таким чином, необхідною умовою проведення техніко-криміналістичних досліджень, а відповідно й обов'язковою ознакою досліджень даного різновиду, є суб'єкт-носій спеціальних криміналістичних знань, умінь і навичок, залучений для проведення відповідного дослідження стороною обвинувачення, стороною захисту чи слідчим суддею.

Наступна істотна ознака технікокриміналістичних досліджень пов'язана з тим, що саме вивчається під час їх проведення, тобто безпосередні об'єкти дослідження.

Аналіз наукових джерел із криміналістики та судової експертизи дозволяє стверджувати, що об'єкти техніко-криміналістичних досліджень $€$ досить різноманітними за своєю природою та сферою застосування (використання), починаючи від різноманітних документів та друкарських форм, закінчуючи різноманітними хімічними речовини та фонограмами. Детальний їх розгляд буде предметом окремого нашого дослідження.

Проте, попри суттєві відмінності в природі та сфері використання (призначенні) об'єктів техніко-криміналістичних досліджень, все ж таки у них є спільна ознака: всі вони $€$ матеріальними, тобто мають своє матеріальне відображення, певну форму в навколишньому світі. Саме ця ознака зазначених об'єктів відрізняє дану категорію досліджень від 
інших досліджень у криміналістиці, оскільки об'єкти останніх можуть бути як матеріальними, так й ідеальними (наприклад, відображеннями подій і фактів у пам'яті людини, припущеннями того, що досліджується, тощо).

Досить часто для проведення техніко-криміналістичних досліджень, окрім спеціальних криміналістичних знань, необхідно використовувати техніко-криміналістичні засоби - певний різновид криміналістичної техніки.

Такі засоби можуть бути досить різноманітними. Згідно з їх класифікацією в криміналістиці це можуть бути й засоби «польової криміналістики», й засоби лабораторної техніки, розроблені як спеціально для цілей криміналістики, так і запозичені з інших галузей науки і техніки [16, с. 94-95].

Однак використання того чи іншого технічного засобу залежить від конкретної ситуації та різновиду техніко-криміналістичного дослідження. Існують випадки, коли для проведення техніко-криміналістичного дослідження технічні засоби можуть взагалі не використовуватись. Наприклад, коли на місці події знаходиться видимий слід пальця руки, утворений нашаруванням речовини темного кольору на світлій поверхні, або коли потрібно оглянути виявлений зразок вогнепальної зброї чи провести почеркознавчу експертизу за текстом, виконаним великим і розбірливим почерком. У такому разі спеціаліст чи експерт можуть обійтись візуальним методом дослідження, без використання жодного додаткового криміналістичного обладнання. Саме тому дана ознака, на наш погляд, $€$ факультативною.

Підсумовуючи вищезазначене, можна зробити такі висновки:

1. До обов'язкових загальних ознак техніко-криміналістичних досліджень у розслідуванні кримінальних правопорушень відноситься:
- сутність техніко-криміналістичних досліджень, як і будь-яких інших досліджень у криміналістиці, полягає в пізнанні (вивченні) певного об'єкта чи об'єктів дослідження;

- метою їх проведення $€$ отримання певної інформації або іï джерел;

- проводяться такі дослідження у зв'язку з розслідуванням конкретних кримінальних проступків чи злочинів, у тому числі для іх розкриття та попередження.

До обов'язкових, окремих ознак, притаманних усім техніко-криміналістичним дослідженням, відносяться такі:

- для проведення дослідження використовуються спеціальні криміналістичні знання - знання в галузі криміналістичної техніки та окремих різновидів криміналістичних експертиз, окремі знання інших розділів криміналістики й інших суміжних галузей науки і техніки, а також відповідні вміння та навички;

- суб'єкти дослідження - особи, які володіють спеціальними криміналістичними знаннями, уміннями та навичками, мають право (наділені повноваженнями) проведення таких досліджень та залучені з цією метою стороною обвинувачення, стороною захисту чи слідчим суддею;

- об'єктами дослідження є матеріальні об'єкти - об'єкти, передбачені теорією криміналістичної техніки та (або) окремих напрямів криміналістичних експертиз.

До факультативних, окремих ознак, притаманних усім техніко-криміналістичним дослідженням, відноситься те, що для проведення досліджень можуть застосовуватися спеціальні техніко-криміналістичні засоби - засоби криміналістичної техніки.

2. Виходячи з окреслених ознак, техніко-криміналістичні дослідження в розслідуванні кримінальних правопорушень - це вивчення матеріальних об’єктів 3 метою 
отримання інформації або виявлення ii джерел, яке здійснюється в ході розслідування кримінальних правопорушень 3 використанням спеціальних криміналістичних знань, умінь, навичок та за потреби - техніко-криміналістичних засобів суб'єктом, який володіє такими знаннями, уміннями та навичками та який правомочний на виконання відповідних досліджень.

3. Поява даного терміна та його широкий ужиток у криміналістиці дозволить об'єднати різні види досліджень в одну групу, чітко окреслити ii та відмежовувати від інших існуючих у криміналістиці досліджень, наприклад, передбачених таким розділом криміналістики, як криміналістична тактика. Це також дозволить розглядати дані дослідження на рівні з іншими базовими для криміналістичної техніки науковими категоріями.

Наукова стаття присвячена розгляду такої базової для криміналістики категорії, як «техніко-криміналістичні дослідження». Наголошується, щзо в більшості випадків у літературі з криміналістики ией термін вживається відносно досліджень документів $i$ ним позначається галузь криміналістичної техніки з однойменною назвою. Водночас термін «техніко-криміналістичні дослідження» без віднесення його до дослідження документів майже не вживається в науковій літературі. Таким чином, на відміну від інших існуючих категорій у криміналістиц̧і, до изього часу чітко не визначено поняття техніко-криміналістичних досліджень та не окреслені їні ознаки. Це призводить до певних проблем як наукового, так $і$ практичного характеру. Для визначення ознак даних досліджень пропонується використовувати два критерії: за належністю та за обов'язковістю. За периим критерієм ознаки техніко-криміналістичних об'єктів можуть бути загальними обов'яз- ковими та окремими. Загальні обов'язкові ознаки пов'язані із сутністю досліджень, метою їх проведення та сферою використання. Загальні обов'язкові у свою чергу передбачають знання, які використовуються в ході досліджень, суб'єктів та об'єкти техніко-криміналістичних досліджень. Факультативні окремі ознаки пов'язані $з$ технічними засобами, які застосовуються піо час проведення таких досліджень. На основі окреслених y роботі ознак зроблено висновок, що техніко-криміналістичні дослідження в розслідуванні кримінальних правопорушень - це вивчення матеріальних об'єктів з метою отримання інформаціï або виявлення ї джерел, яке здійснюеться в ході розслідування кримінальних правопорушень з використанням спеціальних криміналістичних знань, умінь, навичок та за потреби - техніко-криміналістичних засобів суб'єктом, який володіє такими знаннями, уміннями та навичками та який правомочний на виконання відповідних досліджень. Окрім изього, як висновок відстоюється позиція, що поява даного терміна дозволить об'єднати різні види дослідженв в одну групу, чітко окреслити ї та відмежовувати від інших існуючих у криміналістицуі досліджень, а також дозволить розглядати дані дослідження на рівні з іншими базовими для криміналістичної техніки категоріями.

Ключові слова: криміналістична техніка, техніко-криміналістичні дослідження, спеціальні знання.

Areshonkov V. Technicalforensic research as a basic category of forensic technology: concepts and features

The scientific article is dedicated to the consideration of such a basic category for criminology as "technicalforensic research". It is noted that in most cases in the literature on criminalistics, 
this term is used in relation to the study of documents and it refers to the field of forensic science of the same name. At the same time, the term "technicalforensic research" without referring it to the study of documents is almost not used in the scientific literature. It emphasizes that, unlike other existing categories in criminology, the concept of technical forensic research is still not clearly defined and their features are not outlined. This leads to certain problems, both scientific and practical. It is suggested that two criteria be used to determine the characteristics of these studies: relevance and binding. According to the first criterion, the features of technical-forensic objects can be general mandatory and separate. General mandatory features are related to the nature of the research, its purpose and scope. The general requirements in turn include the knowledge used in the course of research, subjects and objects of technical-forensic research. Optional individual features are related to the technical means used in conducting such studies. Based on the features outlined in the paper, it is concluded that technical-forensic research in the investigation of criminal offenses is the study of material objects in order to obtain information or identify its sources, which is carried out during the investigation of criminal offenses using special forensic knowledge, skills, abilities and if necessary, technicalforensic means, an entity that has such knowledge, skills and abilities and which is authorized to perform relevant research. In addition, the conclusion is that the emergence of this term will combine different types of research into one group, clearly define it and distinguish it from other existing research in forensics, as well as allow to consider the dates of the study on a par with other basic categories for forensic techniques.

Key words: forensic technique, technical-forensic research, special knowledge.

\section{Література}

1. Маркусь В.О. Криміналістика навчальний посібник. Київ : Кондор, 2007. 558 c.

2. Криминалистика : учебник для вузов / T.В. Аверьянова и др. ; под ред. Заслуженного деятеля науки Российской Федераиии, профессора Р.С. Белкина. Москва : Издательство НОРМА (Издательская группа НОРМА-ИНФРА М), 2000. 990 c.

3. Криміналістика : підруч. для студ. вищ. навч. закл. / К.О. Чаплинський та ін. 2-е вид, перероб. $i$ доп. Дніпро : Дніпроп. держ. ун-т внутр. справ ; Ліра ЛТД, 2017. 480 c.

4. Дмитриева Т.Ф. Криминалистическое обеспечение осмотра места происшествия: теория и практика : монография ; под науч. ред. Е.И. Климовой. Витебск : ВГУ имени П.М. Машерова, 2016. 307 c.

5. Салтевський М.В. Криміналістика : навчально-довідковий посібник. Киї, 1996. 219 с. C. 93-94.

6. Кофанов А.В., Кобилянський О.Л., Арешонков В.В. Криміналістична техніка : навч. Посібник; за ред. А.В. Кофанова. Київ : «КИЙ», 2011. Книга друга. 4. II. 352 c.

7. Драпкин Л.Я., Карагодин В.Н. Криминалистика : учебник. 2-е изд., перераб. u доп. Москва: Проспект, 2011. 768 с.

8. Лазор Я., Русин Б., Цибочкін В. Програмно-апаратний підхід до техніко-криміналістичних досліджень об'єктів для розкриття злочинів. Вісник Львівського інституту внутрішніх справ. 1996. Випуск 3 Проблеми державотворення.

9. Великий тлумачний словник сучасної української мови / уклад. $і$ голов. ред. В.T. Бусел. Київ ; Ірпінь : ВТФ «Перун», 2002. 1440 c.

10. Словник української мови : в $11 \mathrm{~m}$. / ред. тому : П.П. Доценко, Л.А. Юрчук ; АН УРСР, Ін-т мовознавства імені О.О. Потебні. Київ : Наук. думка, 1971. Т. 2: Г-Ж. 550 с.

11. Криминалистическая экспертиза / Л.Е. Ароикер и др. Москва: Высшая школа МООП РСФСР, 1966. Выпуск I. $166 \mathrm{c}$.

12. Нестеров А.В. Основы экспертной деятельности. Москва : ГУ-ВШЭ, 2009. $168 \mathrm{c}$.

13. Семенов В.В. Спеиіальні знання в розслідуванні злочинів (зміст, організація використання) : автореф. дис. ... 


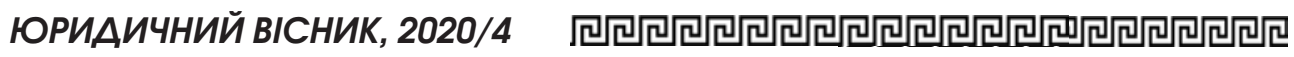

канд. юрид. наук : 12.00.09. Київ : Київ. нац. ун-т внутр. справ, 2006. С. 15.

14. Гончаренко В.Г., Курдюков В.В., Легких К.В. Спеціальні знання: генезис, предмет, рівні, форми використання в доказуванні. Вісник Академії адвокатури України. 2007. № 9. С. 22-34.

15. Фролов О.В. Суб'єкти застосування спеціальних знань у кри- мінальному провадженні на стадіі досудового розслідування. Часопис Академіі адвокатури України. 2014. № 4 (25). T. 7. С. 77-83.

16. Пясковський В.В., Чорноус Ю.М., Самодин А.В. Криміналістика : підручник; за заг. ред. В.В. Пясковского. 2-ге вид., перероб. $i$ допов. Київ : Філія вид-та «Право», 2020.752 c. 